\title{
Aplikasi Kalender Kehamilan (Smart Pregnancy) Berbasis Android
}

\author{
Carudin $^{1}$, Nelly Apriningrum ${ }^{2}$ \\ ${ }^{1}$ Program Studi Teknik Informatika, Fasilkom - Universitas Singaperbangsa Karawang \\ ${ }^{2}$ Program Studi D3 Kebidanan, Fikes - Universitas Singaperbangsa Karawang \\ Jl. H.S. Ronggowaluyo, Telukjambe Timur, Karawang 41361 \\ 1'carudin@cs.unsika.ac.id, ${ }^{2}$ naellyperlote@yahoo.com
}

\begin{abstract}
The calculation of gestational age can be done in various ways. However, the result of evaluation of competence of pregnancy age calculation, estimated birth in obstetric nutrition program in 2016 is still low that only reaches $20 \%$. The weakness of the students' ability in identifying the gestational age was also obtained based on reports from the practice field of students of the Midwifery Department of Unsika. Viewing the data and reports the authors do research by creating an application containing pregnancy calendar on Android OS smartphones. The pregnancy calendar application is designed to make it easier for health workers and potential health care providers to calculate gestational age, pregnancy estimates, and also help pregnant women to control their pregnancies. Based on the assessment by 20 respondents, this pregnancy calendar application is easy to understand and use, and can help midwifes students in predicting HPL. This is seen in all aspects of the assessment, which earn an average percentage of $90 \%$.
\end{abstract}

Keywords- Pregnancy, HPL, Pregnancy Calendar dan Android

\begin{abstract}
Abstrak-Penghitungan usia kehamilan dapat dilakukan dengan berbagai cara. Namun hasil evaluasi kompetensi penghitungan usia kehamilan, taksiran persalinan di prodi kebidanan UNSIKA pada tahun 2016 masih rendah yaitu baru mencapai $20 \%$. Kelemahan kemampuan mahasiswa dalam mengidentifikasi usia kehamilan juga didapatkan berdasarkan laporan dari lahan praktik mahasiswa Prodi Kebidanan UNSIKA. Melihat data dan laporan tersebut penulis melakukan penelitian dengan membuat aplikasi berisi kalender kehamilan pada smartphone OS Android. Aplikasi kalendar kehamilan tersebut dirancang untuk mempermudah tenaga kesehatan dan calon tenaga kesehatan pemberi pelayanan kehamilan dalam menghitung usia kehamilan, taksiran kehamilan, dan juga membantu ibu hamil untuk mengontrol kehamilannya. Berdasarkan hasil penilaian oleh 20 responden, bahwa aplikasi kalendar kehamilan ini dinilai mudah dipahami dan digunakan, serta mampu membantu mahasiswa kebidanan dalam memprediksi HPL. Hal ini terlihat pada semua aspek penilaian, yang mendapatkan persentase rata-rata $90 \%$.
\end{abstract}

Kata kunci- Kehamilan, HPL, Kalendar Kehamilan, Android

\section{PENDAHULUAN}

Program pembangunan pada sektor kesehatan di Indonesia diprioritaskan pada upaya peningkatan derajat kesehatan ibu dan anak, terutama pada kelompok rentan terhadap kesehatan seperti ibu hamil, bersalin, nifas dan bayi. Keberhasilan program tersebut ditentukan berdasarkan Indikator Angka Kematian Ibu (AKI) dan Angka Kematian Bayi (AKB) yang menggambarkan kualitas hidup ibu dan anak di Indonesia.

Data SDKI menyebutkan bahwa AKI dan AKB Indonesia masih cukup tinggi, kematian ibu sebanyak 359/100.000 kelahiran hidup dan AKB sebanyak 32/1000 kelahiran hidup. Masih tingginya AKI dan AKB disebabkan karena faktor penyebab langsung obstetric diantaranya komplikasi kehamilan, persalinan dan nifas. Hal tersebut salah satunya dapat dicegah dengan melakukan deteksi dini resiko tinggi kehamilan. Sedangkan penyebab tidak langsung diantaranya karena penyakit yang diderita ibu sehingga dapat memperberat kehamilan [1][2] . Melihat data tersebut kualitas pelayanan kesehatan ibu dan anak baik pada masa kehamilan, persalinan, nifas dan bayi menjadi krusial untuk diperbaiki.

Periode antenatal merupakan kondisi yang dipersiapkan secara fisik dan psikologis untuk kelahiran dan menjadi orang tua. Pada periode ini terutama seorang ibu akan mencari petunjuk dan melakukan perawatan secara teratur. Kunjungan antenatal biasanya dimulai segera setelah tidak mendapat haid (menstruasi), sehingga dapat diidentifikasi diagnosis dan perawatan terhadap kelainan yang mungkin terjadi pada ibu hamil. Menentukan awal mula kehamilan serta usia kehamilan merupakan hal penting untuk dapat mengetahui perkembangan kehamilannya. Usia kehamilan dapat diketahui salah satunya dengan mengetahui hari pertama haid terakhir (HPHT) seorang perempuan, namun kenyataan di lapangan banyak perempuan yang tidak memperhatikan siklus menstruasinya, hal ini akan dapat mempersulit tenaga kesehatan dalam menentukan usia 
kehamilan secara manual, meskipun saat ini sudah ada alat USG yang dapat mengidentifikasi usia kehamilan, namun demikian informasi HPHT dari seorang ibu dapat memberikan data yang cukup akurat dalam mengidentifikasi kehamilan.

Upaya pemerintah dalam menurunkan AKI dan AKB salah satunya dengan memberikan pelayanan kesehatan yang maksimal, selain itu diperlukan dukungan implementasi pendidikan kesehatan untuk menghasilkan tenaga kesehatan yang kompeten. Pendidikan kebidanan mempunyai andil yang cukup besar dalam memberikan kontribusi untuk menghasilkan tenaga bidan sebagai tenaga kesehatan yang ditempatkan di lini terdepan kesehatan ibu dan anak. Salah satu kompetensi bidan adalah kompeten dadalam memberikan pelayanan kesehatan pada ibu hamil sehat serta mampu mengidentifikasi adanya kelainan dan komplikasi sehingga ibu hamil dengan komplikasi mendapatkan pelayanan yang tepat. Kehamilan sebaiknya dapat diidentifikasi pada awal kehamilan dan usia kehamilan menentukan tenaga kesehatan dalam memberikan asuhan yang tepat pada ibu hamil, dengan demikian setiap bidan dan calon bidan harus mampu menghitung usia kehamilan sebagai salah satu kompetensi yang harus dimilikinya.

Penghitungan usia kehamilan dapat dilakukan dengan berbagai cara. Namun hasil evaluasi kompetensi penghitungan usia kehamilan, taksiran persalinan di prodi kebidanan UNSIKA pada tahun 2016 masih rendah yaitu baru mencapai $20 \%$. Kelemahan kemampuan mahasiswa dalam mengidentifikasi usia kehamilan juga didapatkan berdasarkan laporan dari lahan praktik mahasiswa prodi kebidanan UNSIKA. Melihat data dan laporan tersebut penulis ingin melakukan penelitian dengan membuat aplikasi berisi kalender kehamilan pada smartphone yang merupakan salah satu kemajuan teknologi dewasa ini serta mayoritas masyarakat sudah menggunakan kemajuan teknologi tersebut. Dengan aplikasi tersebut diharapkan dapat mempermudah tenaga kesehatan dan calon tenaga kesehatan pemberi pelayanan kehamilan dalam menghitung usia kehamilan, taksiran kehamilan, taksiran berat janin dan juga membantu ibu hamil untuk mengontrol kehamilannya.

Berdasarkan latar belakang tersebut, peneliti melakukan penelitian dengan tema "Aplikasi kalender kehamilan "smart pregnancy" berbasis android".

\section{METODE PENELITIAN}

\section{A. SIKLUS HAID}

Siklus menstruasi adalah siklus bulanan pada wanita, yang dimulai dari akhir menstruasi sebelumnya sampai akhir menstruasi berikutnya. Siklus ini dibagi dalam tiga fase atau tahap, yaitu fase folikular, ovulasi, dan fase luteal. Siklus menstruasi biasanya sekitar 28 hari (4 minggu bulan komariah), meskipun bisa bervariasi dari wanita ke wanita.

Siklus ini berhenti sementara selama kehamilan dan permanen setelah menopause. [2]

\section{B. KEHAMILAN}

Kehamilan adalah kondisi dimana seorang wanita memiliki janin yang sedang tumbuh di dalam rahimnya. Secara sederhana, untuk terjadi kehamilan diperlukan beberapa syarat yang berasal dari pria maupun wanita.

Masa subur adalah saat ovulasi yaitu saat wanita berada pada masa saat indung telur melepaskan sel telur yang siap untuk dibuahi. Masa subur ini terjadi satu kali dalam satu kali siklus menstruasi [3].

Ada beberapa faktor yang mempengaruhi kesuburan seorang wanita. Secara garis besar, faktor-faktor ini berupa sumbatan pada rahim dan saluran telur, atau juga gangguan hormon yang bisa menyebabkan sel telur gagal matang (kegagalan ovulasi). Sedangkan pada pria dapat berupa[4]:

Kehamilan terjadi selama 40 minggu antara waktu menstruasi terakhir hingga kelahiran atau sekitar 38 minggu dari pembuahan. Istilah medis untuk wanita hamil adalah gravida, sedangkan manusia didalamnya disebut embrio pada minggu-minggu awal dan selanjutnya disebut janin. Sedangkan wanita yang belum pernah hamil dikenal sebagai gravida 0. Menurut Hanifa (2002: 125), "Ada tiga trimester tahap kehamilan yaitu: (1). Trimester Pertama 1-3 bulan, (2). Trimester Kedua 4-6 bulan, (3). Trimester Ketiga 7-9 bulan"[5].

\section{PERHITUNGAN RUMUS NEAGEL}

Untuk menghitung usia kehamilan biasanya dokter menggunakan beberapa petunjuk untuk mengetahui usia kehamilan, yaitu dari kapan pertama kali detak jantung janin dapat didengar dengan alat Doppler (usia kehamilan 10-12 minggu), dari tanda kehidupan janin yang mulai terasa, dari tinggi fundus (puncak Rahim) dan berdasarkan pemeriksaan USG (ultrasonografi).

Berdasarkan usia kehamilan itu, dokter menentukan perkiraan waktu bersalin. Atau bisa juga menggunakan rumus Neagle yang dihitung berdasarkan Hari Pertama Haid Terakhir (HPHT).

Rumus ini biasanya hanya dipakai jika siklus haid teratur 28 - 30 hari.

Rumus Neagle $=($ Hari pertama haid +7$)$, $($ Bulan terakhir haid - 3), (Tahun +1) [6].

\section{ANDROID}

Android merupakan sistem pakar mobile berbasis linux yang mencakup sistem operasi, middleware dan aplikasi. Android menyediakan platform terbuka bagi para pengembang untuk menciptakan aplikasi. Android SDK adalah tools API (Application Programming Interface) yang diperlukan untuk mulai mengembangkan aplikasi pada platform Android menggunakan bahasa pemrograman Java. Android merupakan subset perangkat lunak untuk ponsel yang meliputi sistem operasi, middleware dan aplikasi kunci yang di release oleh Google. Saat ini disediakan Android SDK sebagai alat bantu dan API untuk mulai mengembangkan aplikasi pada platform Android menggunakan bahasa 
pemrograman Java. Sebagai platform aplikasi - netral, android memberikan kesempatan untuk membuat aplikasi yang kita butuhkan yang bukan merupakan aplikasi bawaan Handphone / Smartphone.

\section{E. UML}

Unified Modeling Language (UML) adalah bahasa notasi grafis yang digunakan untuk membuat suatu model visual dari suatu sistem software berbasis Objek.

Fungsionalitas yang ada pada UML dalam penggunaaan aplikasi ini digambarkan dengan menggunakan use case yang merupakan representasi dari alur peristiwa. Use case menggambarkan bagaimana realisasi dari setiap use case yang ada pada model. Syarat penamaan pada use case adalah nama didefinisikan semudah mungkin dan dapat dipahami.[7]

\section{F. RANCANGAN PENELITIAN}

Rancangan penelitian berisi langkah-langkah ilmiah yang digunakan untuk mendapatkan data yang valid, dengan tujuan dapat ditemukan, dikembangkan dan dibuktikan suatu pengetahuan tertentu sehingga dapat digunakan untuk memahami, memecahkan, dan mengantisipasi masalah. Langkah-langkah dalam penelitian ini adalah sebagai berikut:

1. Identifikasi masalah

Tahap awal pada penelitian ini dengan merumuskan masalah yang dijadikan objek penelitian, langkah selanjutnya adalah menentukan tujuan penelitian untuk mendapatkan sasaran yang akan diwujudkan pada penyelesaian permasalahan yang diteliti

2. Tinjauan Pustaka

Tinjauan Pustaka dilakukan untuk mencari literatur pendukung penelitian ini. Pada tahap ini dijelaskan dengan mempelajari aplikasi yang berhubungan dengan konvensional dan digital diary, teori-teori, untuk pengumpulan data dan tools yang digunakan oleh peneliti serta dasar mengenai metode yang digunakan.

3. Pengumpulan Data

Pengumpulan data ada dua cara yaitu dengan melakukan perancangan, pengembangan serta uji penerapan, dan studi literatur untuk pengumpulan data hasil penelitian terdahulu

4. Pembuatan Aplikasi

Dilakukan untuk mengetahui kebutuhan pengguna agar aplikasi yang dikembangkan sesuai dengan kebutuhan pengguna. Metode Pengembangan Sistem pada tahap pengembangan yang akan dipergunakan penulis dalam penelitian ini yaitu menggunakan model SDLC (System Development Life Cycle) dengan menggunakan model/ metode waterfall[8]. Tahapan pembutatan aplikasi diatas terlihat pada pada gambar 1 di bawah ini:

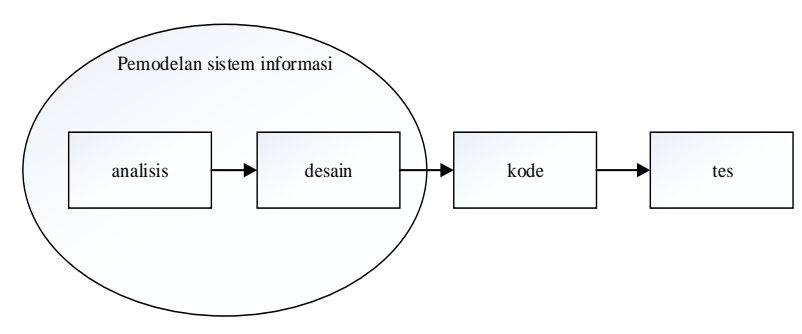

Gambar 1. langkah-langkah penelitian[8]

\section{G. PENGUJIAN BETA}

Pengujian Beta adalah pengujian yang dilakukan oleh user atau pengguna akhir dari perangkat lunak yang telah dibangun. Dalam pengujian beta ini peneliti menggunakan kuesioner yang berisi 5 pertanyaan mengenai usability dari aplikasi kalendar kehamilan yng diebrikan kepada responden. Jawaban hasil kuesioner kemudian dihitung dengan rumus Skala Likert[9] berikut ini untuk mendapatkan kesimpulan.

$$
Y=\frac{X}{i} x 100 \%
$$

Keterangan :

$Y=$ Nilai presentase

$i=$ Skor ideal (skor tertinggi Likert $\mathrm{x}$ jumlah responden)

$$
X=\text { Total skor }
$$

\section{HASIL DAN PEMBAHASAN}

Aplikasi Kalendar Kehamilan berbasis Android ini membantu user yaitu Mahasiswa Kebidanan UNSIKA atau Ibu untuk menghitung usia kehamilan, taksiran kehamilan, dan juga membantu ibu hamil untu mengontrol kehamilannya menggunakan android serta memberikan kemudahan bagi user.

\section{A. USE CASE DIAGRAM}

Use case diagram dalam perancangan aplikasi kelaendar kehamilan ini digunakan untuk menggambarkan hubungan sejumlah sejumlah user/aktor ekternal dengan aplikasi. Gambar 2 di bawah adalah use case diagram yang digambarkan. 


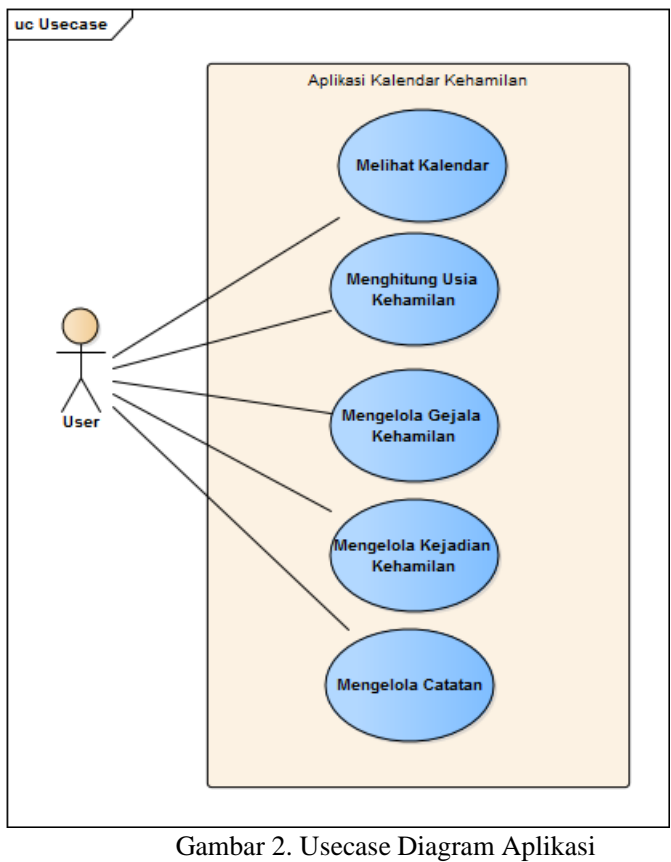

B. IMPLEMENTASI INTERFACE

Berikut ini adalah implementasi interface yang telah dirancang.

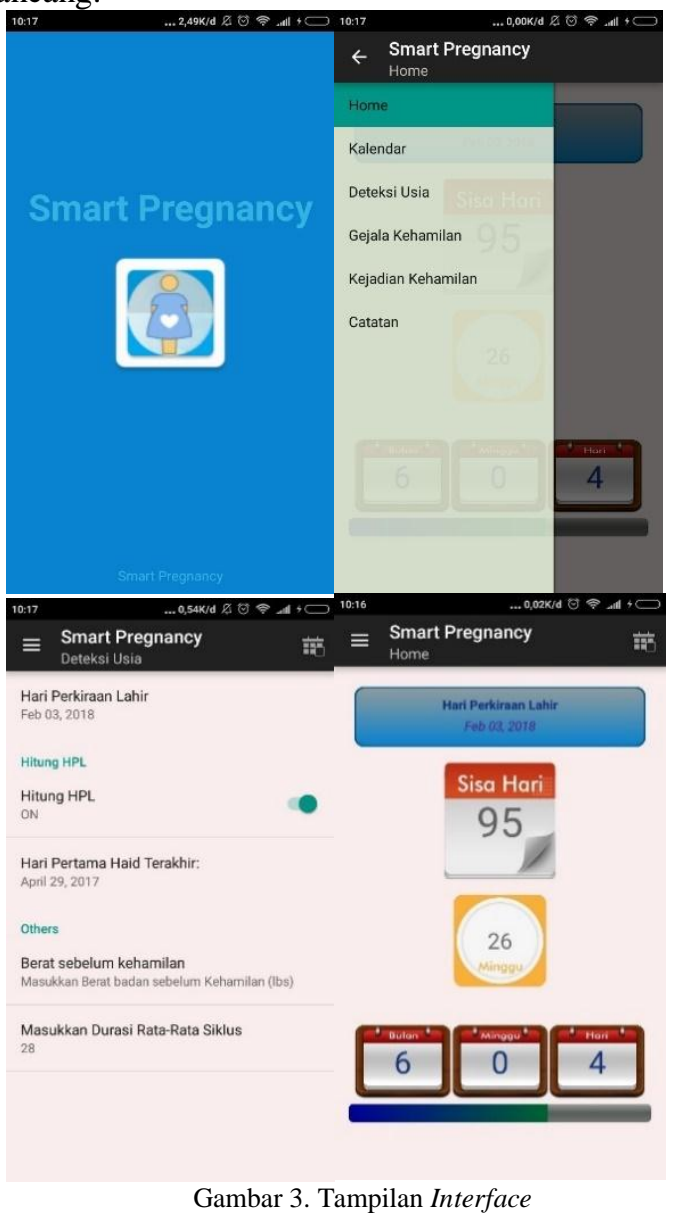

\section{PENGUJIAN BLACK BOX}

Pada bagian tabel 1 ini akan dijelaskan mengenai hasil dari pengujian yang telah dilakukan terhadap sistem.

\begin{tabular}{|c|c|c|c|}
\hline Usecase & Skenario & Target & Hasil \\
\hline Kalendar & $\begin{array}{l}\text { User } \\
\text { mengklik list } \\
\text { kalendar }\end{array}$ & $\begin{array}{l}\text { Sistem } \\
\text { menampilkan } \\
\text { kalendar }\end{array}$ & Oke \\
\hline $\begin{array}{l}\text { Mengitung } \\
\text { Usia } \\
\text { Kehamilan }\end{array}$ & $\begin{array}{l}\text { - User } \\
\text { mengklik } \\
\text { Deteksi Usia } \\
\text { - User } \\
\text { memasukan } \\
\text { Hari } \\
\text { Pertama } \\
\text { Terakhir } \\
\text { Haid } \\
\text { (HPHT) }\end{array}$ & $\begin{array}{l}\text {-Sistem } \\
\text { menampilkan } \\
\text { form } \\
\text { masukan } \\
\text { HPHT dan } \\
\text { rata-rata } \\
\text { siklus haid } \\
\text {-Sistem } \\
\text { menampilkan } \\
\text { Hari } \\
\text { Perkiraan } \\
\text { Lahir (HPL) } \\
\end{array}$ & Oke \\
\hline $\begin{array}{l}\text { Mengelola } \\
\text { Gejala } \\
\text { Kehamilan }\end{array}$ & $\begin{array}{l}\text { - User } \\
\text { mengklik } \\
\text { gejala } \\
\text { kehamilan } \\
\text { - User bisa } \\
\text { menambahk } \\
\text { an, ubah } \\
\text { atau } \\
\text { menghapus } \\
\text { gejala } \\
\text { kehamilan }\end{array}$ & $\begin{array}{l}\text {-Sistem } \\
\text { menampilkan } \\
\text { gejala } \\
\text { kehamilan } \\
\text {-Sistem } \\
\text { melakukan } \\
\text { tambah, } \\
\text { pembaharuan } \\
\text { atau hapus } \\
\text { gejala } \\
\text { kehamilan }\end{array}$ & Oke \\
\hline $\begin{array}{l}\text { Mengelola } \\
\text { Gejala } \\
\text { Kehamilan }\end{array}$ & $\begin{array}{l}\text { - User } \\
\text { mengklik } \\
\text { gejala } \\
\text { kehamilan } \\
\text { - User bisa } \\
\text { menambahk } \\
\text { an, ubah } \\
\text { atau } \\
\text { menghapus } \\
\text { gejala } \\
\text { kehamilan }\end{array}$ & $\begin{array}{l}\text {-Sistem } \\
\text { menampilkan } \\
\text { gejala } \\
\text { kehamilan } \\
\text {-Sistem } \\
\text { melakukan } \\
\text { tambah, } \\
\text { pembaharuan } \\
\text { atau hapus } \\
\text { gejala } \\
\text { kehamilan }\end{array}$ & Oke \\
\hline $\begin{array}{l}\text { Mengelola } \\
\text { Kejadian } \\
\text { Kehamilan }\end{array}$ & $\begin{array}{l}\text { - User } \\
\text { mengklik } \\
\text { kejadian } \\
\text { kehamilan } \\
\text { - User bisa } \\
\text { menambahk } \\
\text { an, ubah } \\
\text { atau } \\
\text { menghapus } \\
\text { kejadian } \\
\text { kehamilan }\end{array}$ & $\begin{array}{l}\text {-Sistem } \\
\text { menampilkan } \\
\text { kejadian } \\
\text { kehamilan } \\
\text {-Sistem } \\
\text { melakukan } \\
\text { tambah, } \\
\text { pembaharuan } \\
\text { atau hapus } \\
\text { kejadian } \\
\text { kehamilan }\end{array}$ & Oke \\
\hline $\begin{array}{l}\text { Mengelola } \\
\text { Catatan } \\
\text { Kehamilan }\end{array}$ & $\begin{array}{l}\text { - User } \\
\text { mengklik } \\
\text { catatan }\end{array}$ & $\begin{array}{l}\text {-Sistem } \\
\text { menampilkan } \\
\text { kejadian }\end{array}$ & Oke \\
\hline
\end{tabular}




\begin{tabular}{llll}
\hline Usecase & Skenario & Target & Hasil \\
\hline & kehamilan & kehamilan \\
& User bisa & - Sistem \\
menambahk & melakukan \\
an, ubah & tambah, \\
atau & pembaharuan \\
menghapus & atau hapus \\
catatan & catata \\
kehamilan & kehamilan \\
\end{tabular}

Pengujian yang dilakukan adalah pengujian black box dimana pengujian ini dilakukan oleh pengembang terhadap fungsionalitas sistem untuk menguji berhasil atau tidaknya suatu fungsionalitas pada setiap user.

\section{PENGUJIAN UJI COBA}

Pengujian uji coba yang telah dilakukan dengan jumlah 20 responden. Kemudian didapatkan nilai persentase dari setiap pertanyaan yang telah diajukan dengan rumus (1).

Tabel 2 menunjukkan hasil perolehan data dari pertanyaan-pertanyaan kuesioner yang diajukan ke 20 responden.

Tabel 2. Hasil perolehan data pengujian

\begin{tabular}{cll}
\hline No & Asepk Penilian & Persentase \\
\hline 1 & Aplikasi Kalendar Kehamilan & $92 \%$ \\
& (Smart Pregnancy) mudah & \\
& digunakan & \\
2 & Aplikasi mudah dipelajari & $90 \%$ \\
3 & Aplikasi memiliki tampilan & $88 \%$ \\
& yang menarik & \\
4 & Aplikasi membantu mahasiswa & $91 \%$ \\
& kebidanan dalam mendeteksi & \\
& HPL \\
5 & Aplikasi dapat menjadi inovasi & $90 \%$ \\
& teknologi untuk pembelajaran \\
\hline
\end{tabular}

\section{IV.PENUTUP}

\section{A. SIMPULAN}

Dari hasil pengujian Aplikasi kalendar kehamilan (Smart Pregnancy) berbasis Android, dapat disimpulkan bahwa :

1. Aplikasi kalendar (Smart Pregnancy) ini dirancang dan dibangun untuk mendeteksi Hari Perkiraan lahir (HPL), Usia kehamilan dan memonitoring kehamilan melalui andorid.

2. Melalui aplikasi ini Mahasiswa Kebidanan dan para ibu dapat melihat gejala kehamilan, kejadian pada saat hamil, mengelola catatan pada saat hamil.

3. Hasil pengujian black box menunjukkan "Oke" pada setiap bentuk pengujian aplikasi yang berarti bahwa semua fungsi pada aplikasi telah bekerja dengan baik.

4. Berdasarkan pengujian aplikasi oleh user diperoleh kelebihan dari aplikasi yaitu memiliki tampilan menarik, mudah digunakan, dan membantu dalam perhitungan HPL.

\section{B. SARAN}

Berdasarkan simpulan di atas maka dapat diusulkan saran demi menunjang efektifitas dari aplikasi yaitu diadakan sosialisasi kepada seluruh mahasiswa kebidanan dan para Ibu dengan adanya aplikasi ini.

\section{REFERENSI}

[1] BPS, BKKN, Kemenkes RI. (2013 ). Laporan Survey Kesehatan Demografi Indonesia (SDKI). Jakarta.

[2] Kemenkes RI, GAVI The Vaccive Alliance. (2016). Buku Ajar kesehatan Ibu dan Anak. Jakarta.

[3] Kamus kesehatan. kamuskesehatan.com. [Online]. http://kamuskesehatan.com/arti/siklus-menstruasi/. Diakses pada tanggal 10 Februari 2017, pada pukul 23.06.

[4] Wikipedia. id.wikipedia.org. [Online]. http://id.wikipedia.org/wiki/Kehamilan. Diakses pada tanggal 10 Februari 2017, pada pukul 23.06.

[5] Bonny D. Hail, Dewi Handajani, dan Natalia Dian Pratiwi.( 2012). 9 Bulan yang Menakjubkan. Jakarta: PT Aspirasi Pemuda.

[6] Wiknjosastro, Hanifa. (2002). Ilmu Kebidanan. Jakarta. Yayasan Bina Pustaka Sarwono Prawirohardjo.

[7] Herlawati P, menggunakan UML (Unified Modelling Language). Jakarta: Informatika, 2011.

[8] Roger S. Pressman, (2002). Rekayasa Perangkat Lunak Pendekatan Praktisi (Buku Satu). Yogyakarta. ANDI.

[9] T. EMS, Android All In One, 1st ed. Jakarta, Indonesia: Elex Media Komputindo, 2013. 